JAMP: Jurnal Adminitrasi dan Manajemen Pendidikan

Volume 4 Nomor 2 Juni 2021, Hal : 187 - 194

Tersedia Online di http://journal2.um.ac.id/index.php/jamp/

ISSN 2615-8574 (online)

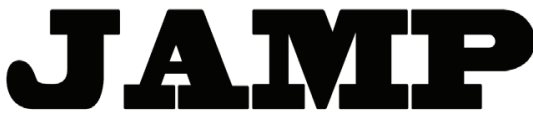

JURNAL ADMINISTRASI DAN MANAJEMEN PENDIDIKAN

\title{
PENGARUH PERSEPSI PROFESI GURU DAN EFIKASI DIRI TERHADAP MINAT MENJADI GURU
}

\author{
Saniyatus Sholichah \\ Triesninda Pahlevi \\ Universitas Negeri Surabaya. Jl. Ketintang Surabaya 60231 \\ E-mail: saniyatussh@gmail.com.
}

\begin{abstract}
This study aims to find the influence of perception of the teacher profession and self-efficacy on the interest of becoming a teacher in students of the Office Administration Education Study Program of the Faculty of Economics, State University of Surabaya Class of 2017. The type in this study is explanatory research with quantitative approach. The data is collected through research instruments using questionnaires. The analysis method is multiple linear regression analysis with SPSS 25 application. The results of the study were: (1) The perception of the teacher profession positively and significantly influenced the interest in becoming a teacher in students of education department of office administration unesa 2017. (2) Self-efficacy does not have a significant influence on the interest in becoming a teacher in students of unesa office administration education program 2017. (3) The perception of the teacher's profession and self-efficacy positively and significantly affect the interest of teachers in students of education department of office administration of UNESA 2017.
\end{abstract}

Keywords: Perception of The Teacher's Profession; Self Efficacy; Interest Becoming a Teacher.

\begin{abstract}
Abstrak: Penelitian ini memiliki tujuan untuk mendapati pengaruh persepsi profesi guru dan efikasi diri terhadap minat menjadi guru pada mahasiswa Program Studi Pendidikan Administrasi Perkantoran Fakultas Ekonomi Universitas Negeri Surabaya Angkatan 2017. Jenis pada penelitian ini yaitu penelitian eksplanatori dengan pendekatan kuantitatif. Data dikumpulkan melalui instrument penelitian dengan menggunakan angket. Metode analisis yaitu analisis regresi linear berganda dengan aplikasi SPSS 25. Hasil penelitian yaitu: (1) Persepsi profesi guru berpengaruh secara positif dan signifikan terhadap minat menjadi guru pada mahasiswa prodi pendidikan administrasi perkantoran UNESA 2017. (2) Efikasi diri tidak memberikan pengaruh yang signifikan terhadap minat menjadi guru pada mahasiswa prodi pendidikan adminitrasi perkantoran UNESA 2017. (3) Persepsi profesi guru dan efikasi diri berpengaruh secara positif dan signifikan terhadap minat mnejadi guru pada mahasiswa prodi pendidikan administrasi perkantoran UNESA 2017.
\end{abstract}

Kata kunci: Persepsi Profesi Guru; Efikasi Diri; Minat Menjadi Guru.

Pendidikan berperan banyak untuk bisa mencerdaskan bangsa. Melalui pendidikan seseorang mendapatkan banyak ilmu pengetahuan, keterampilan, serta pengalaman yang kemudian dapat menumbuhkan kemampuan dan potensi yang dimiliki. Adanya proses pendidikan akan membuat manusia dapat berpikir secara kritis dan sistematis sehingga mampu menghadapi permasalahan yang ada dalam kehidupannya (Wahyuni \& Setiyani, 2017). Pendidikan memiliki banyak unsur penting didalamnya salah satunya yaitu guru. Guru mempunyai tanggung jawab yang kuat agar dapat menentukan keberhasilan dari suatu pendidikan. Akan tetapi, profesi guru tidaklah pekerjaan yang mudah dilakukan.

Pendidikan Administrasi Perkantoran sebagai salah satu jurusan kependidikan di Universitas Negeri Surabaya yang mempersiapkan lulusannya untuk menjadi guru, khususnya guru Administrasi Pertantoran pada sekolah menengah kejuruan. Mahasiswa yang lulus dari bidang pendidikan tentu 
telah paham tentang beban dan kewajiban yang dijalani seorang guru. Untuk itu, minat menjadi factor yang sangat kuat dalam keseharian karena memberikan pengaruh terhadap perilaku dan sikap manusia, sama halnya dengan minat menjadi guru. Memiliki minat menjadi guru dapat mendorong seseorang untuk berperan dan berperilaku sesuai dengan profesi guru (Wahyuni \& Setiyani, 2017). Jika seseorang memiliki keinginan atau minat suatu hal, maka dirinya merasa senang dan tertarik untuk dapat mewujudkan keinginannya.

Sama seperti karir guru jika mahasiswa memiliki minat pada karir guru, mahasiswa semakin bersemangat dan terus berusaha untuk dapat meningkatkan kualitasnya dalam memberikan pendidikan. Menurut penelitian dari Slameto (2010) dituliskan pengertian minat yaitu perasaan gembira dan tertarik akan suatu objek ataupun activity tanpa paksaan dari orang lain, setiap minat akan memberikan suatu kepuasan tersendiri pada seseorang. Selain itu menurut Rahmadiyani dkk. (2020) minat dari mahasiswa kepada pekerjaan guru diakibatkan beberapa aspek yaitu lingkungan keluarga, persepsi profesi guru, dan PLP. Berdasarkan adanya penelitian-penelitian terdahulu maka dapat diambil kesimpulan bahwa minat dari seseorang terhadap profesi guru bisa dipengaruhi banyak faktor, salah satunya yaitu persepsi profesi guru. Hasil wawancara dengan ketua Program Studi, profil lulusan Program Studi Pendidikan Administrasi Perkantoran ialah sebagai akademisi (guru) atau Tenaga Kependidikan Profesional yang memiliki sikap, pengetahuan, keterampilan dan berakhlak mulia, cerdas, dan ahli dalam kompetensi dibidang administrasi perkantoran yang disesuaikan dengan perkembangan teknologi dan informasi, serta berdaya saing internasional. Untuk mendukung profil lulusan tersebut, maka program studi merancang kurikulum kependidikan maupun non kependidikan. Kurikulum kependidikan dituangkan dalam mata kuliah beberapa diantaranya mata kuliah microteaching dan Pengenalan Lapangan Persekolahan (PLP). Kedua mata kuliah tersebut merupakan mata kuliah praktik untuk meningkatkan keterampilan mengajar mahasiswa.

Pada studi pendahuluan, telah dijalankan kegiatan wawancara dengan beberapa mahasiswa Prodi Pendidikan Administrasi Perkantoran Angkatan 2017 Universitas Negeri Surabaya, mahasiswa masih kurang berminat untuk menjadi guru Administrasi Perkantoran. Mereka lebih tertarik pada profesi lain yang lebih menjanjikan dibandingkan guru seperti dosen, wirausaha, pegawai perusahaan, dan lainnya. Mahasiswa masih minim rasa percaya diri terhadap kemampuan yang telah dikantonginya untuk mengajar, meskipun telah melalui mata kuliah microteaching dan mengikuti program Pengenalan Lapangan Persekolahan (PLP). Hal ini menandakan efikasi diri mahasiswa program studi pendidikan administrasi perkantoran masih rendah yang berpengaruh kepada minat dari mahasiswa untuk profesi guru. Nani \& Melati (2020) berpendapat self efficacy atau efikasi diri diartikan sebagai keyakinan dan kapabilitas seseorang dalam menanggulangi tugas tertentu. Minat seseorang dalam memilih suatu profesi merupakan hasil dari efikasi diri yang ada pada dirinya. Ketika seseorang tersebut merasa yakin dan kompeten kemampuannya terhadap suatu pekerjaan, maka minat tersebut terbentuk. Dalam memilih suatu profesi individu harus memiliki keyakinan diri pada profesi tersebut, untuk dapat menghadapi rintangan yang dihadapinya kelak. Persepsi dari seseorang ketika memperhatikan tahap kerumitan suatu pekerjaan tentu berbeda-beda, seseorang menganggap sulit suatu tugas namun ternyata bagi orang lain tugas tersebut tidaklah sulit.

Melalui studi pendahuluan pada Pendidikan Administrasi Perkantoran angkatan 2017 unesa dapat diketahui secara singkat bahwa persepsi mahasiswa terhadap profesi guru sudah sangat baik, mahasiswa telah mengetahui tugas, hak, dan kewajiban seorang guru. Sudut pandang mahasiswa terbentuk berdasarkan ajaran yang telah mereka terima selama masa perkuliahan maupun praktik mengajar. Namun adanya persepsi yang baik tersebut membuat mahasiswa menurunkan minatnya terhadap profesi guru karena merasa tugas guru yang sangat berat, kebanyakan mahasiswa lebih berminat pada dunia perusahaan dan bukan kependidikan. Sukma dkk. (2020) persepsi merupakan sudut pandang dari seseorang kepada suatu sasaran tertentu, pada penelitian ini persepsi profesi guru memiliki arti yaitu bagaimana pandangan dari profesi guru, pada penelitian ini yaitu dari sudut pandang mahasiswa. 


\section{METODE}

Penelitian ini memanfaatkan quantitative approach, yaitu data didapatkan dari sampel populasi penelitian yang selanjutnya dikaji dengan memanfaatkan statistical method dan diinterpretasikan. Sugiyono (2014) berpendapat quantitative research yaitu penelitian yang mengaitkan data dengan wujud angka dan juga analisis statistic. Jenis penelitian ini yaitu penelitian eksplanatori, suatu penelitian yang bertujuan mendapatkan penjelasan dari fenomena yang ada melalui pengujian hipotesis dari hubungan antar variabel (Solimun, 2017). Variabel terikat pada penelitian ini yaitu minat menjadi guru (Y). Sedangkan ada dua variabel independent dalam penelitina ini yaitu persepsi profesi guru (X1) dan efikasi diri (X2), lihat Gambar 1.

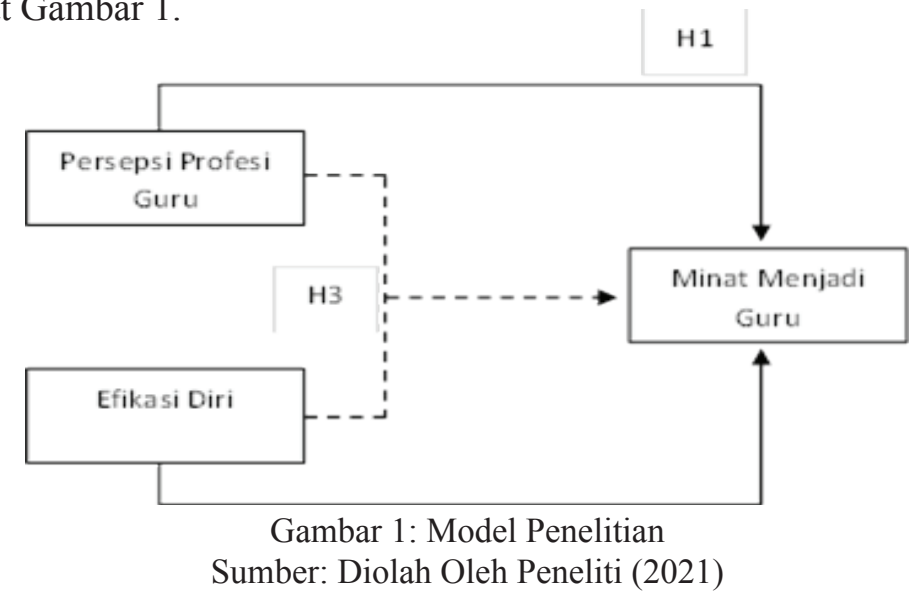

Populasi untuk penelitian ini yaitu mahasiswa aktif dari prodi Pendidikan Administrasi Perkantoran 2017 Fakultas Ekonomi Universitas Negeri Surabaya sebanyak 93 mahasiswa, dan teknik sampling untuk penelitian ini yaitu menggunakan method sampel jenuh yang dalam istilah lain disebut dengan sensus, yang mana sampel dari penelitian ini adalah seluruh populasi (Sugiyono, 2013). Instrumen penelitian ini menggunakan angket dengan memanfaatkan analisis linear berganda.

\section{HASIL}

Variabel persepsi profesi guru $\left(\mathrm{X}^{1}\right)$ diukur melalui indicator peran guru, kompetensi guru, hak-hak guru, dan kewajiban guru. Diperoleh data untuk variable $\mathrm{X}^{1}$ dengan skor maksimal 95 dan skor minimal 19. Hasil analisis menunjukkan mahasiswa dengan persepsi profesi guru sangat tinggi yaitu 63 orang $(68 \%)$, pada kategori tinggi adalah yaitu 28 orang (30\%), dan pada kategori cukup yaitu 2 orang (2\%), sedangkan pada kategori rendah dan sangat rendah tidak ada. Deskripsi frekuensi variable $\mathrm{X}^{1}$ dapat dilihat pada Tabel 1.

Tabel 1. Deskripsi Frekuensi Variabel $\mathbf{X}^{1}$

\begin{tabular}{cccc}
\hline Interval Kelas & Frekuensi & Presentase & Kategori \\
\hline $79-95$ & 63 & $68 \%$ & Sangat Tinggi \\
$64-78$ & 28 & $30 \%$ & Tinggi \\
$49-63$ & 2 & $2 \%$ & Cukup \\
$34-48$ & 0 & $0 \%$ & Rendah \\
$19-33$ & 0 & $0 \%$ & Sangat Rendah \\
\hline
\end{tabular}

Variabel efikasi diri $\left(\mathrm{X}^{2}\right)$ diukur melalui indicator magnitude, generality, dan strength. Diperoleh data untuk variabel $\mathrm{X}^{2}$ dengan skor maksimal 35 dan skor minimal 7. Hasil analisis menunjukkan mahasiswa dengan efikasi diri sangat tinggi yaitu 5 orang (5\%), pada kategori tinggi yaitu 24 orang (26\%), pada kategori cukup yaitu 55 orang (59\%), dan pada kategori rendah yaitu 9 orang $(10 \%)$, sedangkan pada kategori sangat rendah tidak ada. Deskripsi frekuensi variabel $\mathrm{X}^{2}$ dapat dilihat pada Tabel 2. 
Tabel 2. Deskripsi Frekuensi Variabel $\mathrm{X}^{2}$

\begin{tabular}{cccc}
\hline Interval Kelas & Frekuensi & Presentase & Kategori \\
\hline $31-35$ & 5 & $5 \%$ & Sangat Tinggi \\
$25-30$ & 24 & $26 \%$ & Tinggi \\
$19-24$ & 55 & $59 \%$ & Cukup \\
$13-18$ & 9 & $10 \%$ & Rendah \\
$7-12$ & 0 & $0 \%$ & Sangat Rendah
\end{tabular}

Variable minat menjadi guru (Y) diukur melalui 2 indicator yaitu intrinsic dan ekstrinsic. Diperoleh data untuk variabel Y dengan nilai maksimal 17 dan nilai minimal 14. Hasil analisis menunjukkan mahasiswa dengan minat menjadi guru sangat tinggi yaitu 48 orang (52\%), pada kategori tinggi yaitu 29 orang $(31 \%)$, pada kategori cukup yaitu 7 orang (8\%), dan pada kategori rendah yaitu 2 orang $(2 \%)$, sedangkan pada kategori sangat rendah tidak ada. Deskripsi frekuensi variabel Y ditampilkan pada Tabel 3.

Tabel 3. Deskripsi Frekuensi Variabel Y

\begin{tabular}{cccc}
\hline Interval Kelas & Frekuensi & Presentase & Kategori \\
\hline $58-70$ & 48 & $52 \%$ & Sangat Tinggi \\
$47-57$ & 29 & $31 \%$ & Tinggi \\
$36-46$ & 7 & $8 \%$ & Cukup \\
$25-35$ & 2 & $2 \%$ & Rendah \\
$14-24$ & 0 & $0 \%$ & Sangat Rendah \\
\hline
\end{tabular}

Hasil analisis regresi linear berganda dengan nilai constant yaitu $-2,307$ nilai koefisien variable persepsi profesi guru yaitu sebesar 0,557 dan nilai koefisien variable efikasi diri yaitu sebesar 0,362. Maka dapat diketahui persamaan regresi linear berganda yaitu $Y=-2,307+0,557 \mathrm{X}^{1}+0,362 \mathrm{X}^{2}$.

Tabel 4. Hasil Uji T

\begin{tabular}{|c|c|c|c|c|c|c|}
\hline \multicolumn{7}{|c|}{ Coefficients $^{\mathrm{a}}$} \\
\hline & & \multicolumn{2}{|c|}{$\begin{array}{l}\text { Unstandardized } \\
\text { Coefficients }\end{array}$} & \multicolumn{2}{|c|}{$\begin{array}{l}\text { Standardized } \\
\text { Coefficients }\end{array}$} & \multirow[b]{2}{*}{ Sig. } \\
\hline \multicolumn{2}{|c|}{ Model } & B & $\begin{array}{l}\text { Std. } \\
\text { Error }\end{array}$ & Beta & $\mathbf{t}$ & \\
\hline \multirow[t]{3}{*}{1} & (Constant) & $-2,307$ & 9,845 & & & \\
\hline & Persepsi Profesi Guru & 0,557 & 0,114 & 0,452 & 4,889 & 0,000 \\
\hline & Efikasi Diri & 0,362 & 0,213 & 0,157 & 1,700 & 0,093 \\
\hline
\end{tabular}

a. Dependent Variable: Minat Menjadi Guru

Selanjutnya uji T variable persepsi profesi guru $\left(\mathrm{X}^{1}\right)$ dibuktikan pada Tabel 4 didapatkan t hitung 4,889 dengan nilai significancy 0,000 sedangkan t tabel yang dilihat dari tabel statistic dengan nilai significancy $0,05 / 2=0,025$ dan derajat kebebasan $\mathrm{df}=\mathrm{n}-\mathrm{k}-1$ maka dapat diketahui $\mathrm{df}=93-2-1$ sehingga $\mathrm{df}=90$, dapat diketahui $\mathrm{t}$ tabel yaitu sebesar 1,987. Maka diperoleh nilai $\mathrm{t}$ hitung sebesar 4,889 > 1,987 dan significancy $0,000<0,05$ yang artinya persepsi profesi guru memberikan pengaruh positive dan significant untuk minat menjadi guru. Sehingga H1 yang menyatakan terdapat pengaruh positif yang signifikan persepsi profesi guru terhadap minat menjadi guru pada Mahasiswa Program Studi Pendidikan Administrasi Perkantoran Fakultas Ekonomi Universitas Negeri Surabaya Angkatan 2017 dapat diterima. Hasil dari uji $\mathrm{T}$ pada variabel efikasi diri $\left(\mathrm{X}^{2}\right)$ dilihat pada Tabel 4 didapatkan $\mathrm{t}$ hitung 1,700 dan nilai significancy 0,093 . Maka diperoleh nilai t hitung sebesar 1,700<1,987 dan pada nilai significancy $0,093>0,05$ yang berarti efikasi diri tidak memberikan pengaruh yang significant sehingga $\mathrm{H} 2$ yang menyatakan terdapat pengaruh positif yang signifikan efikasi diri terhadap minat menjadi guru pada Mahasiswa Program Studi Pendidikan Administrasi Perkantoran Fakultas Ekonomi Universitas Negeri Surabaya Angkatan 2017 ditolak. 
Tabel 5. Uji F

\begin{tabular}{lllllll}
\hline & \multicolumn{5}{c}{ ANOVA $^{\text {a }}$} \\
\hline \multirow{2}{*}{ Model } & $\begin{array}{l}\text { Sum of } \\
\text { Squares }\end{array}$ & df & Mean Square & F & \multirow{2}{*}{ Sig. } \\
\hline 1 & Regression & 2192,590 & 2 & 1096,295 & 15,211 & $.000 \mathrm{~b}$ \\
& Residual & 6486,722 & 90 & 72,075 & & \\
& Total & 8679,312 & 92 & & & \\
\hline
\end{tabular}

a. Dependent Variable: Minat Menjadi Guru

b. Predictors: (Constant), Efikasi Diri, Persepsi Profesi Guru

Hasil uji $\mathrm{F}$ daitampilkan pada Tabel 5, diperoleh $\mathrm{f}$ hitung yaitu 15,211 sedangkan $\mathrm{f}$ tabel diperoleh dengan derajat keabsahan $\mathrm{dk}=\mathrm{n}-\mathrm{k}$ maka dapat diketahui $2 ; 93-2=2 ; 91$ maka diperoleh $\mathrm{f}$ tabel yaitu sebesar 3,10 . Nilai f hitung $(15,211)>\mathrm{f}$ tabel $(3,10)$ dan pada nilai significancy $0,000<0,05$, sehingga $\mathrm{H} 3$ yang berbunyi terdapat pengaruh positif yang signifikan persepsi profesi guru dan efikasi diri terhadap minat menjadi guru pada Mahasiswa Program Studi Pendidikan Administrasi Perkantoran Fakultas Ekonomi Universitas Negeri Surabaya Angkatan 2017 diterima.

Berdasarkan hasil uji determinasi yang ditampilakn pada table 6 diperoleh nilai koefisien determinasi yaitu 0,253 dapat diambil kesimpulan bahwa besarnya pengaruh yang dapat diberikan oleh persepsi profesi guru $\left(\mathrm{X}^{1}\right)$ dan efikasi diri $\left(\mathrm{X}^{2}\right)$ terhadap minat menjadi guru $(\mathrm{Y})$ yaitu sebanyak $25,3 \%$ yang diartikan bahwa variabel persepsi profesi guru dan efikasi diri memiliki pengaruh unutk minat menjadi guru pada mahasiswa pendidikan administrasi perkantoran fakultas ekonomi universitas negeri surabaya angkatan 2017 yaitu 25,3\% dan sisanya yaitu 74,7\% dapat dipengaruhi oleh variabel lain dari luar penelitian ini.

Tabel 6. Uji Determinasi

\begin{tabular}{lllll}
\hline \multicolumn{5}{c}{ Model Summary } \\
\hline Model & R & R Square & Adjusted R Square & Std. Error of the Estimate \\
\hline 1 & $.503 \mathrm{a}$ & 0,253 & 0,236 & 8,48968 \\
\hline a. Predictors: (Constant), Efikasi Diri, Persepsi Profesi Guru
\end{tabular}

a. Predictors: (Constant), Efikasi Diri, Persepsi Profesi Guru

\section{PEMBAHASAN}

Hasil penelitian yang telah dijalankan menyatakan bahwa $\mathrm{H} 1$ diterima, bahwa pada taraf significant sebesar 0,05 diperoleh nilai significancy sebesar 0,000 dan nilai coefficient 0,557 . Adanya hasil penelitian tersebut maka dapat ditarik kesimpulan bahwa persepsi profesi guru memberikan pengaruh yang positif dan signifikan terhadap minat menjadi guru, hal ini dibuktikan dari adanya hasil dari uji $\mathrm{F}$ dan uji t yang ada dalam kategori baik. Sehingga persepsi profesi guru dapat digunakan sebagai pendukung untuk menumbuhkan minat menjadi guru dari mahasiswa.

Hasil penelitian menunjukkan jika persepsi mahasiswa tentang profesi guru menempati kategori sangat baik, hal itu terjadi karena mahasiswa telah mengetahui dengan baik peran guru, kompetensi guru, serta hak dan kewajiban yang harus dipikul oleh guru. Untuk dapat menumbuhkan minat seseorang terhadap profesi guru maka diperlukan adanya kesiapan yang matang pula terhadap profesi guru, menurut Arikunto (1990) terdapat tiga elemen yang dapat memberikan pengaruh terhadap kesiapan seseorang ketika ingin menggeluti profesi guru diantaranya adalah keilmuan umum, pandangan kepada profesi guru, dan perilaku sebagai guru.

Dalam penelitian persepsi profesi guru mahasiswa pendidikan administrasi perkantoran Universitas Negeri Surabaya menunjukkan pada kategori tinggi. Hasil tersebut diduga karena adanya campur tangan dari kegiatan kependidikan yang dilaksanakan oleh Universitas Negeri Surabaya, khususnya melalui program micro teaching dan program pengenalan lapangan persekolahan (PLP). Melalui kegiatankegiatan tersebut mahasiswa diperkenalkan dan diajarkan untuk mempelajari aspek pembelajaran dan pengelolaan pendidikan, mahasiswa juga terjun secara langsung untuk mengajar siswa di sekolah. Dari adanya kegiatan tersebut mahasiswa dapat mengetahui lebih dalam bagaimana komplikasi dari profesi 
guru. Melalui kegiatan tersebut juga mahasiswa dapat menginterpretasikan segala bentuk penjelasan yang bersinggungan dengan profesi guru, penjelasan yang didapat bukan hanya dari bentuk teoritis namun juga dilengkapi dengan pengalaman praktik mengajar yang telah dilaksanakan. Hal tersebut yang membuat mahasiswa dapat memahami bagaimana semangat dan kondisi yang sesungguhnya yang bersangkutan dengan profesi guru, sehingga mahasiswa akan lebih memantapkan dirinya kelak saat menjadi seorang guru. Penelitian Ajzen (1991:188) dalam theory of planned behavior menyatakan bahwa ada tiga hal yang dapat menajdi pengaruh untuk minat seseorang salah satunya yaitu norma subyektif, dalam norma subyektif disebutkan apabila pandangan dari seseorang terhadap suatu objek akan memberikan pengaruh kepada minatnya dalam memperhitungkan bagaimana dirinya ketika ingin berperilaku.

Hasil penelitian membuktikan $\mathrm{H} 2$ ditolak, bahwa pada taraf significant sebesar 0,05 diperoleh nilai significancy sebesar 0,093 dan nilai koefisien sebesar 0,362. Dari hasil tersebut dapat disimpulkan bahwa efikasi diri tidak memiliki pengaruh yang significant terhadap minat menjadi guru, yang artinya meskipun efikasi diri mahasiswa ada pada kategori baik (positif) maka tidak akan mempengaruhi tingkat minatnya terhadap profesi guru, begitu juga sebaliknnya ketika tingkat efikasi diri mahasiswa ada pada kategori buruk (negatif) maka tidak akan mempengaruhi minatnya terhadap profesi guru. Hal itu terjadi karena mahasiswa Pendidikan Administrasi Perkantoran Universitas Negeri Surabaya masih memiliki rasa percaya diri yang rendah untuk dapat menjadi guru professional, merasa tugas dan tanggung jawab dari profesi guru sangatlah berat meskipun mahasiswa telah memiliki kemampuan mengajar yang baik.

Namun, mahasiswa masih tetap menaruh minat yang tinggi kepada profesi guru lantaran ilmu keguruaan yang mahasiswa pelajari, mahasiswa masih kurang yakin dengan dirinya sendiri meskipun kemampuan yang dimilikinya sudah cukup baik. Penelitian ini bertentangan dengan hipotesis peneliti yaitu efikasi diri berpengaruh positif dan signifikan terhadap minat menjadi guru pada mahasiswa program studi Pendidikan Administrasi Perkantoran Fakultas Ekonomi Universitas Negeri Surabaya Angkatan 2017. Hal tersebut dimungkinkan terjadi karena meskipun mahasiswa yakin telah mampu menjelaskan pelajaran dengan maksimal kepada murid dengan baik, tidak gugup dan percaya diri namun masih belum dapat meyakinkan diri mahasiswa untuk dapat menjadi guru yang professional karena tugas dan tanggung jawab profesi guru sangatlah berat. Didukung dengan penelitian Ardiansyah, dkk. (2012) yang menyatakan seorang guru dituntut untuk harus memiliki, menguasai, dan melaksanakan kompetensi sesiai dengan yang telah disyaratkan, oleh karena itu tugas dan fungsi guru haruslah dilaksanakan dengan professional. Perbedaan taraf efikasi diri mahasiswa dapat diakibatkan oleh beberapa factor yaitu kesuksesan dalam keahliannya, pengalaman orang lain, bujukan dari orang lain, situasi psikologi dan emosional (Bandura, 2010). Selanjutnya dari penelitian Caprara, dkk. (2005) membuktikan efikasi diri seseorang tidaklah muncul secara alami, namun didapatkan dari hasil output dari pengetahuan yang dirinya dapatkan, kewajiban, hubungan yang berbeda, manfaat suatu pekerjaan, dan korelasi yang telah dilakukan dengan orang lain.

Hasil penelitian membuktikan $\mathrm{H} 3$ diterima, hasil dari uji $\mathrm{F}$ pada taraf significant sebesar 0,05 didapatkan nilai significancy 0,000 dan nilai f hitung lebih besar dari $\mathrm{f}$ tabel 15,211 > 3,10. Maka H3 diterima yang artinya persepsi profesi guru dan efikasi diri memberikan pengaruh yang positif dan signifikan terhadap minat menjadi guru. Berdasarkan output dari analisis linear berganda antara persepsi profesi guru dan efikasi diri terhadap minat menjadi guru diperoleh persamaan regresi $\mathrm{Y}=-2,307+$ $0,557 \mathrm{X}^{1}+0,362 \mathrm{X}^{2}$. Dapat diketahui persamaan tersebut mempunyai nilai constant negative $-2,307$ yang artinya apabila persepsi profesi guru dan efikasi diri bernilai nol maka minat menjadi guru bernilai negatif. Dari persamaan regresi tersebut dapat diartikan bahwa satu satuan skor minat menjadi guru dipengaruhi oleh persepsi profesi guru sebesar 0,557 dan efikasi diri sebesar 0,362 pada konstanta -2,307. Maka, jika persepsi profesi guru dan efikasi diri sebesar nol maka minat menjadi guru adalah $-2,307$. Berdasarkan output tersebut maka hipotesis ketiga diterima.

Untuk dapat menghasilkan guru yang berbobot dan kompeten perlu adanya kesiapan yang matang bagi calon guru, ada banyak factor yang menjadi pengaruh bagi kesiapan seseorang untuk mengajar, salah satunya yaitu minat (Mulyasa, 2008). Minat dari seseorang tidak muncul dengan sendirinya tetapi karena beberapa unsur yang telah mereka miliki yang nantinya dibutuhkan. Shaleh \& Wahab (2004) 
berpendapat bahwa minat dipengaruhi oleh bobot, umur, gender, pengalaman, perasaan mampu, dan keprobadian. Selanjutnya menurut Abror (1993) ada tiga unsur minat yaitu kognisi (mengenal), asumsi (perasaan), dan konasi (kehendak). Maksudnya untuk dapat menumbuhkan minat dalam diri seseorang maka diperlukan adanya perkenalan terlebih dahulu, yang kemudian diikuti dengan prasangka atau dugaan terhadap suatu obyek tersebut, dalam hal ini persepsi profesi guru diperlukan untuk dapat mendeskripsikan obyek tersebut yang kemudian dapat diwujudkan dengan unsur selanjutnya yaitu kehendak, unsur kehendak ini dapat diwujudkan melalui bentuk keinginan, usaha, dan juga keyakinan, yang artiya efikasi diri juga akan memberikan dorongan terhadap seseorang untuk dapat menumbuhkan minatnya.

Mahasiswa Pendidikan Administrasi Perkantoran telah memiliki persepsi profesi guru yang sangat baik meskipun efikasi diri berada pada kategori cukup dan perlu untuk dikembangkan kembali, namun hal itu tidak melunturkan minat mahasiswa terhadap profesi guru, adanya dukungan penuh dari orang tua menjadi satu diantara beberapa indicator yang menumbuhkan minat mahasiswa kepada profesi guru. Diperkuat juga dengan teori dari penelitian Hurlock (2010) yang menyatakan adanya beberapa elemen yang dapat memberikan pengaruh minat seseorang kepada profesi guru yaitu, perilaku orang tua, kedudukan suatu pekerjaan, ketakjuban pada orang lain, gender, keahlian dan keinginan, peluang menjadi independen, pengalaman pribadi, dan stereotip budaya. Dari penjelasan tersebut diketahui sikap orang tua menjadi salah satu factor yang memberikan dampak terhadap minat orang lain dalam mempertimbangkan suatu pekerjaan, yang mana sikap orang tua adalah gambaran dari perilaku ataupun dukungan dari orang tua kepada minat anaknya. Persepsi profesi guru dan efikasi diri berpengaruh terhadap minat menjadi guru pada mahasiswa Pendidikan Administrasi Perkantoran Fakultas Ekonomi Universitas Negeri Surabaya Angkatan 2017, hal ini dibuktikan dari besarnya tunjangan nilai efektif dari variabel independent terhadap variabel dependen sebesar $25,3 \%$.

\section{SIMPULAN}

Bersumber pada hasil analisis data penelitian dan pembahasan diperoleh kesimpulan bahwa: (1) persepsi profesi guru yang dimiliki mahasiswa pendidikan administrasi perkantoran Universitas Negeri Surabaya ada pada kategori sangat baik, hal ini menunjukkan pelaksanaan pelaksanaan micro teaching dan PLP memberikan dampak yang baik; (2) efikasi diri yang dimiliki mahasiswa pendidikan administrasi perkantoran Universitas Negeri Surabaya masih pada kategori cukup, meskipun kemampuan yang dimiliki sudah baik namun mahasiswa belum cukup yakin dapat menjadi guru professional; (3) minat yang dimiliki mahasiswa pendidikan administrasi perkantoran Universitas Negeri Surabaya ada pada kategori sangat baik, adanya persespi profesi guru yang baik dan dukungan lingkungan keluarga membuat mahasiswa tetap berminat pada profesi guru; (4) persepsi profesi guru memiliki pengaruh positive dan significant terhadap minat menjadi guru pada mahasiswa Program Studi Pendidikan Administrasi Perkantoran Fakultas Ekonomi Universitas Negeri Surabaya Angkatan 2017 (5) efikasi diri tidak memiliki pengaruh yang significant terhadap minat menjadi guru pada mahasiswa Program Studi Pendidikan Administrasi Perkantoran Fakultas Ekonomi Universitas Negeri Surabaya Angkatan 2017 (6) persepsi Profesi Guru dan Efikasi Diri memiliki pengaruh positive dan significant terhadap Minat Menjadi Guru pada Mahasiswa Program Studi Pendidikan Administrasi Perkantoran Fakultas Ekonomi Universitas Negeri Surabaya Angkatan 2017

Saran yang dapat disampaikan peneliti: (1) mahasiswa diharapkan untuk dapat memperluas persepsi mengenai profesi guru secara mendalam dan meningkatkan efikasi diri dengan mengeksploirasi kemampuan pada bidang lain yang dirasa masih belum dapat dikuasai serta belajar untuk dapat menyelesaikan tugas yang lebih sulit. (2) Bagi peneliti selanjutnya diharapkan penelitian ini diharapkan bagi peneliti selanjutnya untuk dapat melakukan penelitian lebih mendalam mengenai minat pada perofesi guru dan dapat menjadikan penelitian ini sebagai refrensi bagi peneliti selanjutnya, khususnya bagi penelti yang ingin mengambil topik dan variabel berkaitan dengan minat menjadi guru. 


\section{DAFTAR RUJUKAN}

Abror, A. R. (1993). Psikologi Pendidikan. Yogyakarta: PT Tiara Wacana.

Ajzen, I. (1991). The Theory of Planned Behavior. Organizational Behavior and Human Decision Processes, 50 , 179-211.

Ardiansyah, L., Handoyo, S. S., \& Neolaka, A. (2012). Persepsi mahasiswa terhadap profesi guru ( studi penelitian pada mahasiswa program studi S1 pendidikan teknik bangunan universitas negeri jakarta ). Jurnal PenSil Jurusan Teknik Sipil FT UNJ, I(2), 95-102. Diambil dari http://journal.ujn.ac.id

Arikunto, S. (1990). Manajemen Pengajaran Secara Manusiawi. Jakarta: Raneke Cipta.

Bandura, A. (2010). Self efficacy. The Corsini encyclopedia of psychology. New York: W.H. Freeman and Company.

Caprara, Vittorio, G., \& Steca, P. (2005). Self-efficacy beliefs as determinants of prosocial behavior conducive to life satisfaction across ages. Journal of Social and Clinical Psychology, 24(2), 191-217.

Hurlock, E. B. (2010). Psikologi Perkembangan Jilid 2 (Terj. Meit). Jakarta: Erlangga.

Mulyasa, E. (2008). Kompetensi dan Sertifikasi Guru. Bandung: PT. Remaja.

Nani, E. F., \& Melati, I. S. (2020). Peran Self Efficacy Dalam Memediasi Motivasi, Persepsi Profesi Guru Dan Gender Terhadap Minat Menjadi Guru. Economic Education Analysis Journal, 2(1), 487-502. https://doi. org/10.15294/eeaj.v9i2.39542

Rahmadiyani, S., Hariani, L. S., \& Yudiono, U. (2020). Minat Menjadi Guru: Persepsi Profesi Guru, Pengenalan Lapangan Persekolahan (PLP) dan Efikasi Diri. Jurnal Riset Pendidikan Ekonomi, 5(1). https://doi. org/10.21067/jrpe.v5i1.4304

Shaleh, A. R., \& Wahab, M. A. (2004). Psikologi Suatu Pengantar dalam Perspektif Islam. Jakarta: Prenada Media. Slameto. (2010). Belajar dan Faktor-faktor yang Mempengaruhinya. Jakarta: Rineka Cipta.

Sugiyono. (2013). Metode Penelitian Kuantitatif, Kualitatif, dan R\&B. Bandung.

Sukma, A. N., Karlina, E., \& Priyono. (2020). Pengaruh Persepsi Profesi Guru Terhadap Minat Menjadi Guru Pada Mahasiswa Pendidikan. Research and Development Journal Of Education, 1(1), 110-116. Diambil dari https://journal.lppmunindra.ac.id/index.php/RDJE

Wahyuni, D., \& Setiyani, R. (2017). Pengaruh Persepsi Profesi Guru, Lingkungan Keluarga, Efikasi Diri Terhadap Minat Menjadi Guru. Economic Education Analysis Journal, 6(3), 669-683. Diambil dari http://journal. unnes.ac.id/sju/index.php/eeaj 